\title{
Correlation between Rainfall and Mass Movements in North Coast Region of Sao Paulo State, Brazil for 2014-2018
}

\author{
Daniel Metodiev, Marcio Roberto Magalhaes de Andrade, Rodolfo Moreda Mendes, \\ Marcio Augusto Ernesto de Moraes, Tehrrie Konig, Cassiano Antonio Bortolozo, \\ Tiago Bernardes, Rafael Alexandre Ferreira Luiz, Juliano Oliveira Martins Coelho
}

\begin{abstract}
National Center for Monitoring and Early Warning of Natural Disasters (CEMADEN), Sao Jose dos Campos, Sao Paulo, Brazil Email: daniel.metodiev@cemaden.gov.br, marcio.andrade@cemaden.gov.br, rodolfo.mendes@cemaden.gov.br, marcio.moraes@cemaden.gov.br, tehrrie.pacheco@cemaden.gov.br, cassiano.bortolozo@cemaden.gov.br, tiago.bernardes@cemaden.gov.br, rafael.luiz@cemaden.gov.br, juliano.coelho@cemaden.gov.br
\end{abstract}

How to cite this paper: Metodiev, D., de Andrade, M.R.M., Mendes, R.M., de Moraes, M.A.E., Konig, T., Bortolozo, C.A., Bernardes, T., Luiz, R.A.F. and Coelho, J.O.M. (2018) Correlation between Rainfall and Mass Movements in North Coast Region of Sao Paulo State, Brazil for 2014-2018. International Journal of Geosciences, 9, 669-679. https://doi.org/10.4236/ijg.2018.912040

Received: November 20, 2018 Accepted: December 24, 2018 Published: December 27, 2018

Copyright (c) 2018 by authors and Scientific Research Publishing Inc. This work is licensed under the Creative Commons Attribution International License (CC BY 4.0).

http://creativecommons.org/licenses/by/4.0/

\begin{abstract}
The monitoring of related hourly and accumulated rainfall index requires that critical thresholds of accumulated 72 hours rainfall are updated frequently according with the factors and local conditions (natural and anthropic) of each specific risk area. The importance of empirical methods is fundamental to confirm the relationship between rainfall intensity and accumulated rainfall with the mass movement events, in order to establish the critical threshold values. The present work performs an evaluation of the record data of mass movement events occurred in Sao Paulo State North coast region for a 4-year period (2014 to 2018) considering different mass movement characteristics (slope type, magnitude and impact level). Some rainfall values were obtained to show that within these parameters an event related to natural and anthropic features was triggered. A database was created, sorting source of information and municipalities monitored, to implement the correlation between the mass movement events and the rainfall values. To elaborate the event's map, reliable record data of localization of the mass movement events was selected, as well as the nearest possible raingauges of CEMADEN (National Center for Monitoring and Early Warning of Natural Disasters); also the exact event triggering time, selection by the slope type, the magnitude and the impact level of the mass movement event. The rainfall values of these raingauges allowed the calculation of the accumulated rainfall index for $1,3,6,24,48,72$ and 96 hours, with the adoption of the 72 hours index for this work. The correlation graphics are divided by the slope type, the magnitude and the impact level of the mass movement event. Different
\end{abstract}


critical thresholds appear, classifying such event by the influence level of triggering factors, natural and/or anthropic.

\section{Keywords}

Mass Movement Events, Rainfall Intensity, Accumulated Rainfall, Critical

Thresholds, Sao Paulo State-Brazil

\section{Introduction}

Accordingly with the United Nations (1993) the mass movements are one of the natural phenomena that cause the most financial impact and deaths in the world. The mass movements assume catastrophic proportions in urban areas causing structural damages and human losses. In Brazil rainfall is the principal natural factor that causes floods, riverside collapses, intensification of erosional processes and evidently, they decisively contribute to mass movement triggering. As a result of specifically geological risk scenarios natural processes may occur in different scales becoming disasters and catastrophes with huge material and social impact [1]. Civil Defense Preventive Plan-PPDC (in Portuguese) was elaborated in 1988, specifically to attend the frequent mass movements in Serra do Mar Mountain slope in Sao Paulo State. PPDC constitutes an important technical tool for management, monitoring and control of mass movement risk areas. Evacuation of vulnerable population living insusceptible areas, before the mass movement events occur, is a main prevention al action of the PPDC.

The main operability of PPDC involves the monitoring of the related rainfall values (hourly and accumulated 72 hours rainfall index), as well as weather forecast, field inspection and emergency situations [2]. Currently, these activities are developed in ten regions of Sao Paulo State, considering that Baixada Santista and Litoral Norteare two of them. The PPDC deals with preventive actions of mass movement associated risk in slope and talus areas inappropriate for occupation.

Therefore, the aim of this study is to present the interaction between the accumulated $6 \mathrm{~h} \times 72 \mathrm{~h}$ rainfall correlated with the triggering time of the mass movement events in connection of the critical pluviometric thresholds [3]. The last is of extreme importance for the functional efficiency of the PPDC preventive actions. It is suggested an evaluation model of the mass movement events' register and the rainfall database for a 4-year period (2014 to 2018) in Baixada Santista and Litoral Norte regions (Figure 1). The intention is to perform an actualization and classification of the critical thresholds. This may be considered a very important empirical tool for the landslide risk management efficiency due to the preventive action improvement and the social/material impact mitigation.

\section{Methodology and Development of the Proposed Model}

Figure 2 presents the proposed model applied in area which is situated on Sao 


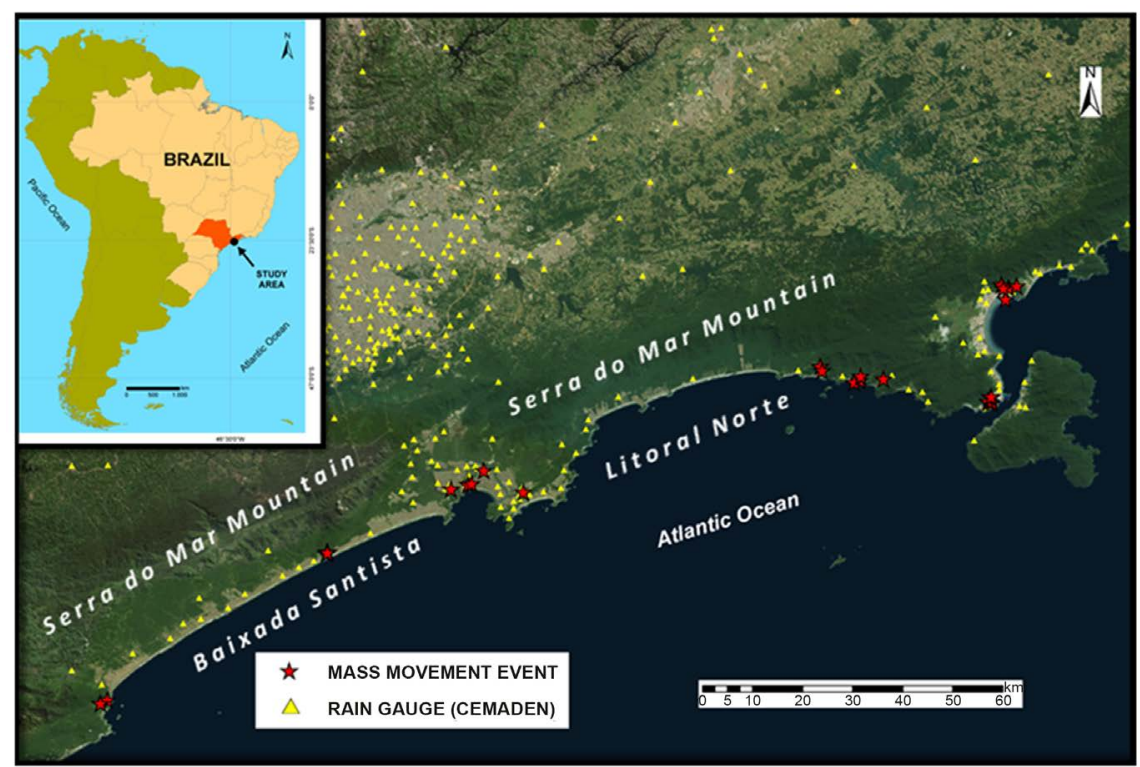

Figure 1. Map of the study area with geographic position of the CEMADEN rain gauge network and the evaluated mass movement events.

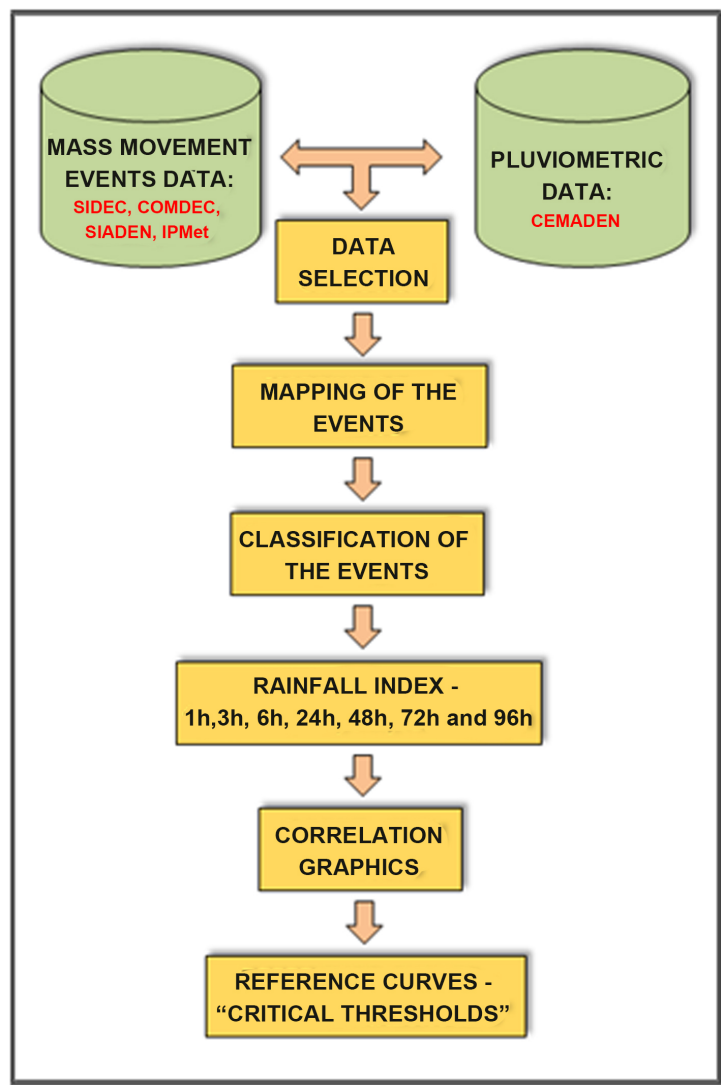

Figure 2. Flowchart of sequential stages to correlation between rainfall values and mass movement events.

Paulo State north coast between Serra do Mar Mountains and the South Atlantic Ocean. This area covers 13 municipalities-Peruibe, Itanhaem, Mongagua, Praia 
Grande, Sao Vicente, Cubatao, Santos, Guaruja and Bertioga (Baixada Santistaregion) and SaoSebastiao, Ilhabela, Caraguatatuba and Ubatuba (Litoral Norteregion). The mass movement susceptibility varies of each COMDEC (Regional Civil Defense Municipality Units) attendance area of all these 13 municipalities, being a reflex of the physical factors and conditions (lithological and pedological substrate, relief, slope position and declivity, vegetal covering, pluviometric precipitation patterns, etc), as well as the anthropic conditions of the risk area (environmental degradation, slope cut, dumped landfills and embankments on top of the talus, pipe leakages and other).

\subsection{Mass Movement Events Data}

For development of this study mass movement events data has been acquired from official registers [4], such as the Civil Defense Integrated System of Sao Paulo State (SIDEC), which includes field inspection reports of the Sao Paulo State Geological Institute (IG) and of the Institute of Technological Research (IPT).

Other data sources that could be used-COMDEC (Regional Civil Defense Municipality Units), Meteorological Research Institute (IPMet) of the State University of Sao Paulo (UNESP) and of the newly created database of the Natural Disaster Alerting System (SIADEN) of CEMADEN, but these data sources will be included and analyzed at the next stage of the study. The correlations in this work were elaborated with SIDEC mass movement events data, essentially (Table 1).

\subsubsection{Data Selection}

There were evaluated 32 mass movement event registers, but some of them (8) cannot be used due to absence of important data, such as correct date and time of the event. For example, the lack of event time or confusion on the report tab page between triggering time and Civil Defense actioning/attending time, and the lack of correct event location (wrong coordinates or/and incomplete addresses). These generate a lot of uncertainties on the organization of the mass movement database [5]. A generalization of all type of events during their registration process mixing and confusing different events and disasters is a common mistake in the field reports. For example, mixing of landslides with riverside and roadside collapses, floods and rainfall torrents, gravitational soil subsidences, falling/slumping of rock blocks and other. Another important factor to be considered in an empirical correlation study is the distance between the rain gauges and the mass movement events. Inexistence of rain gauges within a distance of 3 $\mathrm{km}$ from the event to be analyzed makes the correlation results more abstract, especially the critical thresholds.

\subsubsection{Mapping of the Events}

Is necessary to geo-reference the coordinates (latitude and longitude) to provide the correct location of each mass movement event data, as well as to identify the 
Table 1. An example for elaboration of mass movement events database for Baixada Santista and Litoral Norte regions for a 2014 to 2018 period (source: SIDEC).

\begin{tabular}{|c|c|c|c|c|c|c|c|}
\hline $\mathbf{N}$ & MUNICIPALITY & $\mathrm{LOCA}^{\prime}$ & $\mathrm{ION}^{1}$ & TYPE & MAGNITUDE $^{2}$ & IMPACTS $^{3}$ & DATE/TIME ${ }^{4}$ \\
\hline \multicolumn{8}{|c|}{ BAIXADA SANTISTA region } \\
\hline 92 & Guaruja & $7,347,705$ & 372,006 & $\begin{array}{c}\text { Natural slope/dumped } \\
\text { landfill }\end{array}$ & $500 \mathrm{~m}^{3}$ & $\begin{array}{l}44 \text { remov. residents/ } \\
11 \text { interd. housing }\end{array}$ & $26 / 03 / 14-16.00 \mathrm{~h}$ \\
\hline 118 & Mongagua & $7,335,069$ & 336,162 & Slope cut & $4 \mathrm{~m}^{3}$ & $\begin{array}{l}8 \text { remov. residents/ } \\
3 \text { interd. housing }\end{array}$ & $28 / 02 / 16-22.40 \mathrm{~h}$ \\
\hline 119 & Mongagua & $7,335,343$ & 336,331 & $\begin{array}{l}\text { Natural/slope cut/ } \\
\text { compacted landfill }\end{array}$ & $5 \mathrm{~m}^{3}$ & $\begin{array}{l}13 \text { remov. residents/ } \\
3 \text { interd. housing }\end{array}$ & $29 / 02 / 16-00.30 \mathrm{~h}$ \\
\hline 120 & Mongagua & $7,335,318$ & 336,319 & Natural/slope cut & $10 \mathrm{~m}^{3}$ & $\begin{array}{l}4 \text { remov. residents/ } \\
4 \text { interd. housing }\end{array}$ & $29 / 02 / 16-06.00 \mathrm{~h}$ \\
\hline 146 & Santos & $7,351,980$ & 364,754 & Slope cut/dumped landfill & $90 \mathrm{~m}^{3}$ & $\begin{array}{l}12 \text { remov. residents/ } \\
3 \text { interd. housing }\end{array}$ & $23 / 01 / 15-01.40 \mathrm{~h}$ \\
\hline 147 & Santos & $7,349,107$ & 361,915 & Slope cut/dumped landfill & $600 \mathrm{~m}^{3}$ & $\begin{array}{l}64 \text { remov. residents/ } \\
16 \text { interd. housing }\end{array}$ & $23 / 01 / 15-00.50 \mathrm{~h}$ \\
\hline 148 & Santos & $7,349,230$ & 361,593 & Natural slope & $960 \mathrm{~m}^{3}$ & $\begin{array}{l}0 \text { remov. residents/ } \\
0 \text { interd. housing }\end{array}$ & $23 / 01 / 15-02.30 \mathrm{~h}$ \\
\hline 163 & Sao Vicente & $7,348,211$ & 358,756 & Compacted landfill & no data & $\begin{array}{l}0 \text { remov. residents/ } \\
0 \text { interd. housing }\end{array}$ & $21 / 01 / 17-17.40 \mathrm{~h}$ \\
\hline \multicolumn{8}{|c|}{ LITORAL NORTE region } \\
\hline 48 & Caraguatatuba & $7,389,376$ & 462,078 & Slope cut & $100 \mathrm{~m}^{3}$ & $\begin{array}{l}28 \text { remov. residents/ } \\
7 \text { interd. housing }\end{array}$ & $31 / 01 / 15-20.00 \mathrm{~h}$ \\
\hline 49 & Caraguatatuba & $7,386,697$ & 460,046 & Slope cut & $41 \mathrm{~m}^{3}$ & $\begin{array}{l}8 \text { remov. residents/ } \\
2 \text { interd. housing }\end{array}$ & $23 / 03 / 16-22.00 \mathrm{~h}$ \\
\hline 50 & Caraguatatuba & $7,389,634$ & 459,494 & slope cut & $15 \mathrm{~m}^{3}$ & $\begin{array}{l}28 \text { remov. residents/ } \\
7 \text { interd. housing }\end{array}$ & $15 / 03 / 17-05.00 \mathrm{~h}$ \\
\hline 51 & Caraguatatuba & $7,389,181$ & 460,017 & Natural slope/debris flow & no data & $\begin{array}{l}60 \text { remov. residents/ } \\
15 \text { interd. housing }\end{array}$ & $15 / 03 / 17-05.30 h$ \\
\hline 151 & Sao Sebastiao & $7,366,229$ & 457,076 & Natural/slope cut & $100 \mathrm{~m}^{3}$ & $\begin{array}{l}12 \text { remov. residents/ } \\
3 \text { interd. housing }\end{array}$ & $23 / 12 / 14-16.40 \mathrm{~h}$ \\
\hline 153 & Sao Sebastiao & $7,366,081$ & 457,654 & Natural/slope cut & $90 \mathrm{~m}^{3}$ & $\begin{array}{l}20 \text { remov. residents/ } \\
5 \text { interd. housing }\end{array}$ & $15 / 01 / 16-03.20 \mathrm{~h}$ \\
\hline 155 & Sao Sebastiao & $7,372,365$ & 426,521 & Natural slope & $3000 \mathrm{~m}^{3}$ & $\begin{array}{l}148 \text { remov. residents/ } \\
37 \text { interd. housing }\end{array}$ & $29 / 02 / 16-04.50 \mathrm{~h}$ \\
\hline 157 & Sao Sebastiao & $7,370,362$ & 433,404 & Natural slope & $320 \mathrm{~m}^{3}$ & $\begin{array}{l}24 \text { remov. residents/ } \\
6 \text { interd. housing }\end{array}$ & $29 / 02 / 16-05.10 \mathrm{~h}$ \\
\hline 158 & Sao Sebastiao & $7,370,014$ & 432,415 & Natural/slope cut & $160 \mathrm{~m}^{3}$ & $\begin{array}{l}0 \text { remov. residents/ } \\
1 \text { interd. housing }\end{array}$ & $29 / 02 / 16-05.10 \mathrm{~h}$ \\
\hline 159 & Sao Sebastiao & $7,371,245$ & 433,533 & Natural slope/debris flow & $800 \mathrm{~m}^{3}$ & $\begin{array}{l}20 \text { remov. residents/ } \\
5 \text { interd. housing }\end{array}$ & $29 / 02 / 16-05.10 \mathrm{~h}$ \\
\hline 160 & Sao Sebastiao & $7,370,747$ & 437,769 & Natural/slope cut & $900 \mathrm{~m}^{3}$ & $\begin{array}{l}26 \text { remov. residents/ } \\
7 \text { interd. housing }\end{array}$ & $29 / 02 / 16-05.30 \mathrm{~h}$ \\
\hline 176 & Ubatuba & $7,404,719$ & 491,165 & Slope cut & $250 \mathrm{~m}^{3}$ & $\begin{array}{l}6 \text { remov. residents/ } \\
3 \text { interd. housing }\end{array}$ & $23 / 02 / 18-01.00 \mathrm{~h}$ \\
\hline 178 & Ubatuba & $7,404,657$ & 491,033 & Slope cut & $80 \mathrm{~m}^{3}$ & $\begin{array}{l}8 \text { remov. residents/ } \\
4 \text { interd. housing }\end{array}$ & $23 / 02 / 18-01.00 \mathrm{~h}$ \\
\hline
\end{tabular}




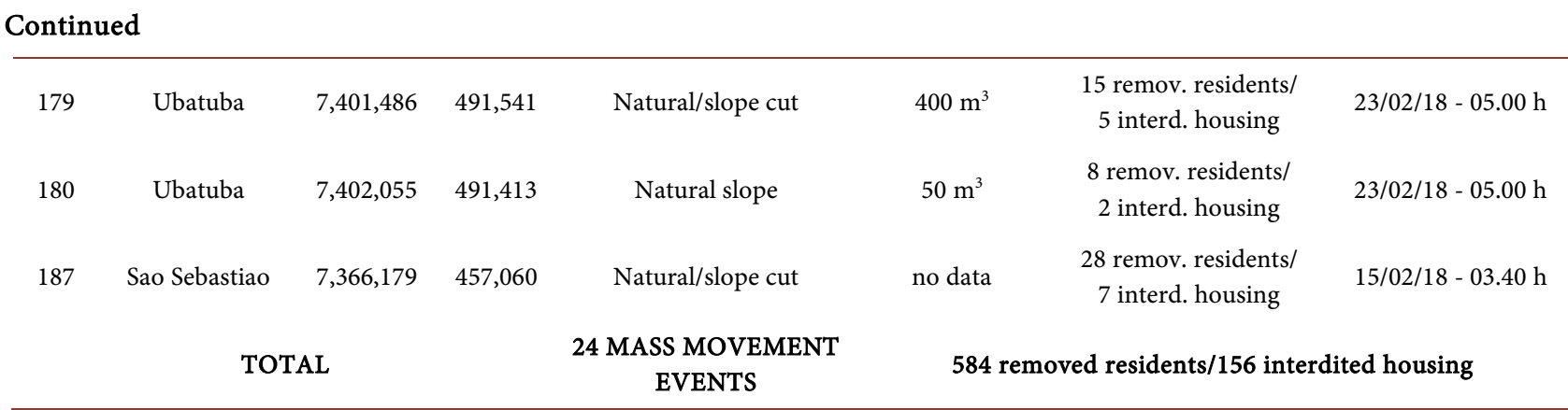

${ }^{1}$ UTM Location of Fuse 23 South. ${ }^{2}$ Estimated Volume of Mobilized Mass Material. ${ }^{3}$ Interim and/or Permanent Measures and Actions. ${ }^{4}$ GMT Revised Date/Time.

rain gauges within the radius of the pluviometric influence. It is very important detail before to start the acquisition and processing of the rainfall triggering values [6]. From the data spatial positioning is possible to connect the important key-points (mass movement events/rain gauges) with existing thematic data of the area-geological, geotechnical, geomorphological and pedologicalmaps of the region, but also with urban development municipal layouts from the last 20 - 30 years [7].

\subsubsection{Classification of the Events}

The classification of landslide and mud/debris flow events allows making a more detailed evaluation with regard to the proportions and the triggering causes in order to define the critical thresholds of each mass movement event locality:

- Typology of the events-were prioritized only translational/rotational landslides, natural/induced, mud/debris flows. The correlation graphic (Figure 3) considers a classification of the events divided by sloping rupture and sloping movement type: natural slope (1), dumped/compacted landfill (2) andslope cut (3).

- Magnitude-it was estimated considering the total volume of the mobilized material $\left(\mathrm{m}^{3}\right)$ in mass movement volumescale (Figure 4): low $<15 \mathrm{~m}^{3}(1)$, medium low $16-100 \mathrm{~m}^{3}$ (2), medium high $101-500 \mathrm{~m}^{3}$ (3), high $501-1000$ $\mathrm{m}^{3}$ (4), very high $>1001 \mathrm{~m}^{3}$ (5) and not available data (6).

- Impact and damages-a classification was adopted by 4 (four) groups of affected houses (Figure 5): low < 2 (1); medium low 3 - 6 (2); medium high 7 10 (3) and high $>11$ (4).

\subsection{Pluviometric Data}

Rainfall data was obtained directly from the information platform of the CEMADEN monitoring automatic pluviometric network. To select all specific rainfall data, a 3 kilometers effective distance was adopted between the mass movement event location and the closest rain gauge in operation (Table 2). Due to the absence of any rain gauges in the proximity of some mass movement events the distance less than 3 kilometers is not recommended. Depending on the type and the scale of the triggering rainfall (Isolated Tropical Convection or 


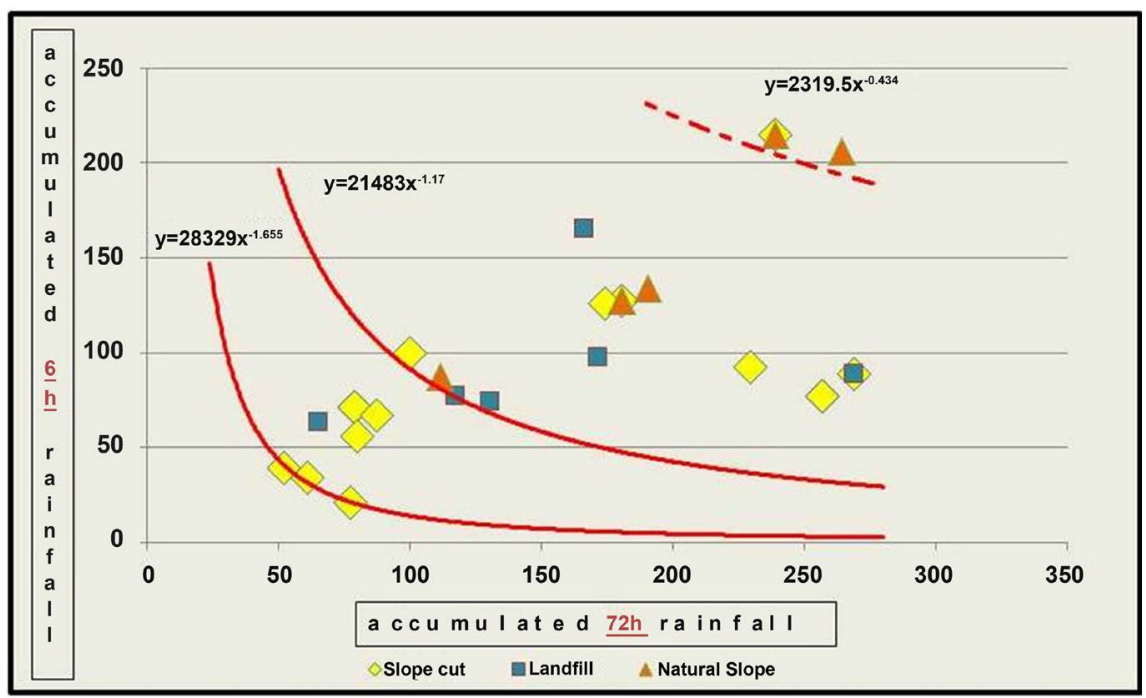

Figure 3. Graphic showing the relation between accumulated $6 \mathrm{~h} \times 72$ hrainfall from the local time of the mass movement events divided by the type of the slope and the talus rupture.

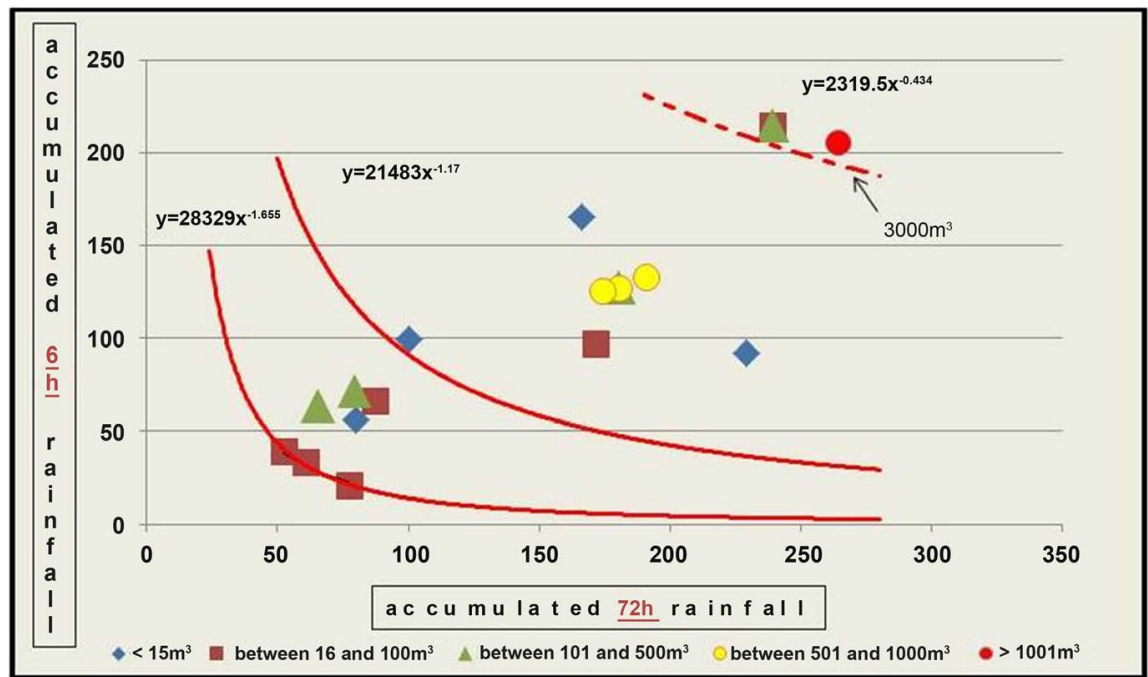

Figure 4. Graphic showing the relation between accumulated $6 \mathrm{~h} \times 72 \mathrm{~h}$ rainfall from the local time of the mass movement events divided by magnitude $\left(\mathrm{m}^{3}\right)$.

Table 2. Correlation between mass movement event time and accumulated rainfall index for Baixada Santista/Litoral Norte regions (pluviometric data source: CEMADEN).

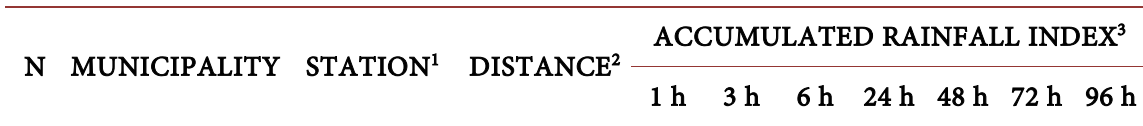

\section{BAIXADA SANTISTA region}

\begin{tabular}{ccccccccccc}
92 & Guaruja & $351870119 \mathrm{~A}$ & 1.014 & 49.3 & 63.5 & 63.5 & 64.9 & 64.9 & 65.3 & 111.4 \\
118 & Mongagua & $353110003 \mathrm{~A}$ & 2.755 & 74.6 & 99.4 & 99.4 & 99.4 & 99.4 & 100.2 & 100.2 \\
119 & Mongagua & $353110003 \mathrm{~A}$ & 3.050 & 36.0 & 144.0 & 165.3 & 165.3 & 165.3 & 166.1 & 166.1 \\
120 & Mongagua & $353110003 \mathrm{~A}$ & 3.022 & 1.2 & 2.6 & 92.5 & 228.5 & 228.5 & 229.3 & 229.3 \\
\hline
\end{tabular}




\section{Continued}

\begin{tabular}{|c|c|c|c|c|c|c|c|c|c|c|}
\hline 146 & Santos & $354850013 \mathrm{~A}$ & 1.272 & 26.7 & 72.2 & 97.5 & 119.1 & 171.7 & 171.7 & 171.7 \\
\hline 147 & Santos & $355100903 \mathrm{~A}$ & 0.599 & 18.1 & 55.6 & 74.0 & 106.1 & 130.5 & 130.5 & 130.5 \\
\hline 148 & Santos & $355100903 \mathrm{~A}$ & 1.237 & 33.2 & 93.9 & 133.6 & 145.0 & 190.5 & 190.5 & 190.5 \\
\hline 163 & Sao Vicente & $355100904 \mathrm{~A}$ & 0.931 & 36.3 & 76.8 & 76.8 & 85.7 & 101.5 & 117.6 & 138.3 \\
\hline \multicolumn{11}{|c|}{ LITORAL NORTE region } \\
\hline 48 & Caraguatatuba & $351050017 \mathrm{~A}$ & 0.447 & 3.5 & 10.0 & 20.8 & 77.2 & 77.2 & 77.2 & 77.2 \\
\hline 49 & Caraguatatuba & $351050007 \mathrm{~A}$ & 2.800 & 21.4 & 66.8 & 66.8 & 66.8 & 66.8 & 87.3 & 87.3 \\
\hline 50 & Caraguatatuba & $351050010 \mathrm{~A}$ & 1.802 & 55.1 & 55.9 & 56.1 & 68.8 & 80.0 & 80.0 & 80.0 \\
\hline 51 & Caraguatatuba & $351050010 \mathrm{~A}$ & 1.082 & 66.3 & 87.3 & 87.5 & 99.8 & 111.4 & 111.4 & 111.4 \\
\hline 151 & Sao Sebastiao & $355070409 \mathrm{~A}$ & 0.778 & 32.1 & 33.7 & 33.7 & 48.0 & 60.9 & 60.9 & 60.9 \\
\hline 153 & Sao Sebastiao & $355070409 \mathrm{~A}$ & 0.378 & 11.4 & 23.6 & 39.2 & 43.5 & 43.7 & 52.2 & 63.7 \\
\hline 155 & Sao Sebastiao & $355070411 \mathrm{~A}$ & 0.135 & 82.3 & 86.3 & 205.9 & 258.5 & 258.5 & 264.2 & 264.2 \\
\hline 157 & Sao Sebastiao & $355070406 \mathrm{~A}$ & 0.86 & 84.6 & 88.2 & 127.3 & 177.5 & 177.5 & 180.5 & 180.5 \\
\hline 158 & Sao Sebastiao & $355070406 \mathrm{~A}$ & 1.128 & 84.6 & 88.2 & 127.3 & 177.5 & 177.5 & 180.5 & 180.5 \\
\hline 159 & Sao Sebastiao & $355070406 \mathrm{~A}$ & 0.828 & 84.6 & 88.2 & 127.3 & 177.5 & 177.5 & 180.5 & 180.5 \\
\hline 160 & Sao Sebastiao & $355070419 \mathrm{~A}$ & 1.655 & 88.7 & 89.7 & 126.1 & 173.6 & 173.8 & 174.2 & 174.2 \\
\hline 176 & Ubatuba & $355540606 \mathrm{~A}$ & 1.877 & 27.0 & 31.5 & 71.3 & 73.3 & 79.0 & 79.2 & 79.8 \\
\hline 178 & Ubatuba & $355540606 \mathrm{~A}$ & 2.019 & 27.0 & 31.5 & 71.3 & 73.3 & 79.0 & 79.2 & 79.8 \\
\hline 179 & Ubatuba & $355540623 \mathrm{~A}$ & 2.602 & 7.5 & 109.0 & 215.1 & 230.7 & 238.7 & 238.9 & 241.1 \\
\hline 180 & Ubatuba & $355540623 \mathrm{~A}$ & 2.259 & 7.5 & 109.0 & 215.1 & 230.7 & 238.7 & 238.9 & 241.1 \\
\hline 187 & Sao Sebastiao & $355070409 \mathrm{~A}$ & 0.797 & 26.2 & 58.1 & 77.4 & 214.9 & 224.3 & 257.0 & 257.0 \\
\hline
\end{tabular}

${ }^{1}$ Nearest Pluviometric Station (CEMADEN); ${ }^{2}$ Distance in $\mathrm{km} ;{ }^{3}$ Percipitation in $\mathrm{mm}$.

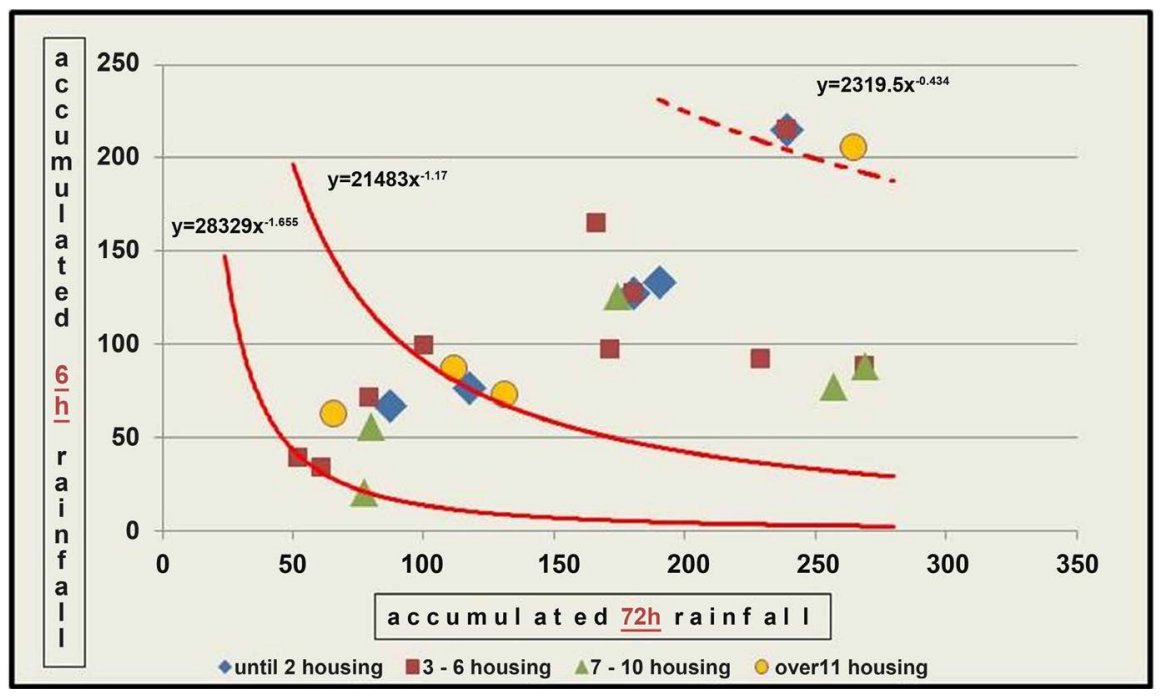

Figure 5. Graphic showing the relation between accumulated rainfall $6 \mathrm{~h} \times 72 \mathrm{~h}$ from the local time of the mass movement events divided by the impact level: affected houses.

Cold Front), the distance higher than 3 kilometers puts at risk the quality and relevance of the correlation results obtained. 


\section{Rainfall Index}

In Baixada Santista and Litoral Norte regions, rainfall values related to each individual mass movement event (32) were the basis for definition of the critical thresholds and their associated triggering rainfalls. The CEMADEN automatic pluviometric network sends the rainfall values acquired with 10 minutes frequency. Pluviometric indices were calculated according to the studies of Tatizana et al. [8] and Santoro et al. [9]. These studies present de relation between accumulated rainfall in 1, 3, 6, 24, 48, 72 and 96 hours. In correlation graphics can be observed that accumulated $6 \mathrm{~h} \times 72 \mathrm{~h}$ rainfall index relation could divide some mass movement events groups [10], indicating specific critical thresholds between each type of event (Figures 3-5).

\section{Correlation Graphics between Mass Movement Events and Rainfall: Critical Threshold Elaboration}

In Figures 3-5 stands out that many mass movement events are triggered due to rainfall intensity or/and accumulated precipitation regime below the PPDC official critical threshold pattern [8] and [11]. For induced landslides in the regions Baixada Santista and Litoral Norte a new critical thresholds values of the triggering rainfall can be suggested. They could be considerably less of the PPDC proposed triggering reference lines. Then mass movement events present low critical thresholds could stay far below of the Tatizana et al. [8] triggering reference line. They could be associated with a high contribution of several triggering anthropic actions [12].

Critical thresholds by the type of the slope and the talus rupture-the graphic suggests that the slope cut landslides could have lower triggering thresholds than the PPDC proposed (Figure 3). Dumped landfill landslides are triggered in $50 \mathrm{~mm} / 72 \mathrm{~h}$ accumulated precipitation index, natural slope landslides occurring above of $100 \mathrm{~mm} / 72 \mathrm{~h}$ accumulated precipitation index and debris/mud flows usually occurring above of $220 \mathrm{~mm} / 72 \mathrm{~h}$ accumulated precipitation index.

Critical thresholds by magnitude-the graphic suggests that an accumulated rainfall above of $50 \mathrm{~mm} / 72 \mathrm{~h}$ precipitation index could cause high magnitude landslides (Figure 4).

Critical thresholds by the impact-the graphic suggests that accumulated rainfall above of $50 \mathrm{~mm} / 72 \mathrm{~h}$ of precipitation index could cause medium to high impact landslides (Figure 5).

Main critical threshold line-the graphic suggests that the principal critical threshold line is fixed in $100 \mathrm{~mm}$ (accumulated $72 \mathrm{~h}$ rainfall index) separating rainfall triggered mass movement events from induced events by anthropic factors (Figure 6). In the zone above the critical line, the events data presents higher level of accuracy than in the zone below this line that presents lower accuracy level.

Is important to highlight that between the first $(50 \mathrm{~mm})$ and the second (100 


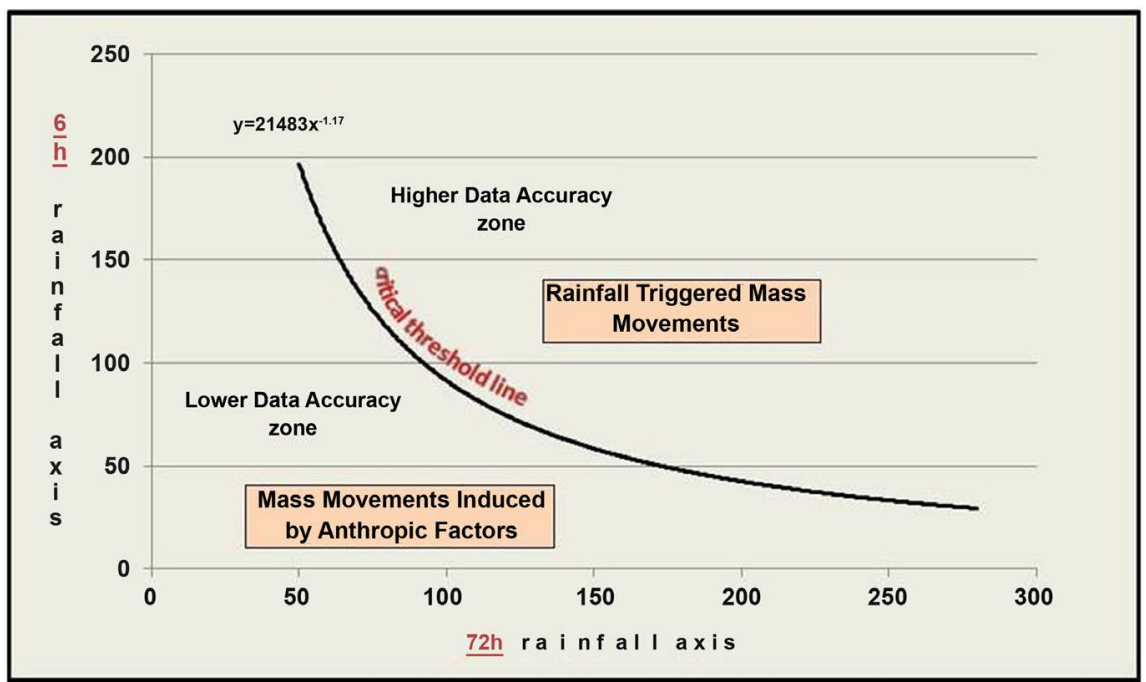

Figure 6. Graphic showing the most relevant critical threshold line separating natural from induced mass movement event zones.

$\mathrm{mm}$ ) critical threshold line there is clear evidence of interaction between the inducing and the natural triggering factor. However, when the critical threshold line increase, the level of data uncertainties reduce. The same happen when the critical threshold line decrease and inducing factor begins to prevail, the level of data uncertainties reduce.

\section{Conclusions}

The results, although preliminary, indicate some relevant trends on analysis, which point to reach a better understanding of the mass movement dynamics in the regions concerned. The COMDEC (Regional Civil Defense Municipality Units) data sources and nonevent rainfall data to be incorporated in the future will allow more consistency of the mass movement event analysis and could confirm these correlations.

This kind of data in Brazil, such as rainfall values as well as mass movement event data, is very sparse and hampers the robust analysis, making more difficult the critical threshold actualization with the necessary precision. That takes the critical threshold definition at even lower levels, which can create a disproportionately large amount of alerts, many of them without any associated mass movement event.

\section{Conflicts of Interest}

The authors declare no conflicts of interest regarding the publication of this paper.

\section{References}

[1] Tominaga, L.K. (2012) Escorregamentos. In: Tominaga, L.K., Santoro, J. and Amaral, R., Eds., Desastres Naturais. Conhecer para prevenir 2, GeologicalInstitute, Sao Paulo/SP, 2.

[2] Mendes, R.M., Valério Filho, M., Bertoldo, M.A. and Silva, M.F. (2015) Estudos de 
limiares críticos de chuva deflagradores de deslizamentos no município de São José dos Campos (Brasil). In: Territorium, Coimbra/PT, 22, 119-129.

[3] Jamaludin, S. and Ali, F. (2011) An Overview of Some Empirical Correlations between Rainfall and Shallow Landslides and Their Applications in Malaysia. Electronic Journal of Geotechnical Engineering, 16, 1429-1440.

[4] Ide, F.S. (2005) Escorregamento, meteorologia e precipitação: Uma proposta de método de investigação para prevenção e monitoramento de riscos, aplicado em Campinas/SP. Master's Thesis, Technological Research Institute-IPT, Sao Paulo.

[5] Fernandez, G.N. (2018) Determinação de limiares críticos de chuva deflagradores de movimentos gravitacionais de massa, Município de São Bernardo do Campo, SP. Master's Thesis, Geosciences Institute, University of Sao Paulo, USP, Sao Paulo/SP, $126 \mathrm{p}$.

[6] D’Orsi, R., D’Ávila, C., Ortigão, J.A.R., Dias, A., Moraes, L. and Santos, M.D. (1997) Rio-Watch: The Rio de Janeiro landslidewatch system. In Conference: Conferência Brasileira Sobre Estabilidade de Encostas 2, Rio de Janeiro/RJ, 1997, Vol. 1, 21-30.

[7] Alheiros, M.M., Souza, M.A.A., Bitoun, J., Medeiros, S.M.G.M. and Amorim Jr., W.M. (2003) Manual de ocupação de morros da Região Metropolitana de Recife. Recife: Fundação de Desenvolvimento Municipal, Recife/PE, 384 p.

[8] Tatizana, C., Ogura, A.T., Cerri, L.E.S. and Rocha, M.C.M. (1987) Modelamento numérico da análise de correlação entre chuvas e escorregamentos aplicado às encostas da Serra do Mar no município de Cubatão. In: Anais do Congresso Brasileiro de Geologia de Engenharia 5, São Paulo/SP, 1987b, 2, 237-248.

[9] Santoro, J., Mendes, R.M., Pressinotti, M.M.N. and Manoel, G.R. (2010) Correlação entre chuvas e deslizamentos ocorridos durante a operação do plano preventivo de defesa civil em São Paulo, SP. In: Anais do Simpósio Brasileiro de Cartografia Geotécnica e Geoambiental 7, Maringá/PR, 2010, 1-15.

[10] Guidicini, G. and Iwasa, O.Y. (1976) Ensaio de correlação entre pluviosidade e escorregamentos em meio tropical úmido. In: Technological Research Institute-IPT, 1080, Sao Paulo, 1-48.

[11] Elbachá, A.T., Campos, L.E.P. and Bahia, R.F.C. (1992) Tentativa de correlação entre precipitação e deslizamentos na cidade de Salvador. In Conference: Conferência Brasileira Sobre Estabilidade de Encostas 1, Rio de Janeiro/RJ, 1992.

[12] Parizzi, M.G., Sebastião, C.S., Viana, C.S., Pflueger, M.C., Campos, L.C., Cajazeiro, J.M.D., Tomich, R.S., Guimarães, R.N., Abreu, M.L., Sobreira, F.G. and Reis, R. (2010) Correlação entre chuvas e movimentos de massa no município de Belo Horizonte, MG. In Geografias, Belo Horizonte/MG, Vol. 6, 2, 49-68. 